\title{
The acceptability of weekly iron-folic acid supplementation and its influencing factors among adolescent school girls in Yogyakarta city: a mix- methods study
}

\author{
Muhammad Ridwan Ansari ${ }^{1}$, BJ Istiti Kandarina ${ }^{2^{*}}$, Nuraini Kusmayanti ${ }^{1}$, \\ Destriyani $^{3}$, Masfufah ${ }^{4} \&$ Rizka Fikrinnisa ${ }^{5}$ \\ ${ }^{1}$ Centre for Tropical Medicine, Faculty of Medicine, Public Health, and Nursing, \\ Universitas Gadjah Mada, Indonesia; ${ }^{2}$ Department of Biostatistics, Epidemiology, \\ and Population Health, Faculty of Medicine, Public Health, and Nursing, Universitas \\ Gadjah Mada, Indonesia; ${ }^{3}$ Puskesmas Pambusuang, Poliwali Mandar; ${ }^{4}$ Nutrition \\ Study Program, STIKes Widya Nusantara, Palu; ${ }^{5}$ Faculty of Health and Pharmacy, \\ Universitas Adiwangsa Jambi
}

\begin{abstract}
Introduction: Indonesia has initiated the weekly iron-folic acid supplementation programme (WIFS) among adolescent school girls since 2016. However, its acceptability needs to be investigated. This study aimed to assess the acceptability of WIFS and its influencing factors. Methods: A mixed-methods study was conducted in six schools in Yogyakarta from January-April 2018. Totally, 211 participants aged 12-18 years were involved in the cross-sectional survey, followed by four focus group discussions (FGDs) and in-depth interviews (IDIs). Body mass index-for-age, haemoglobin, serum ferritin, habitual intake, and acceptability (defined as selfreported iron-folic acid tablet consumption) were assessed. Results: This study reported that $22.3 \%$ and $12.4 \%$ of the participants were categorised as iron deficient and anaemic, respectively. Almost $90 \%$ of participants had received the tablet, but only $62.0 \%$ of them reported consuming it. Logistic regression test indicated that the participants were more likely to take the tablet if it tasted good [OR $(95 \% \mathrm{CI})$ : 4.66 (1.90-11.43)]. Meanwhile, motivation for tablet consumption declined when respondents perceived the odour of tablet was unpleasant, reported forgetfulness, lacked peer support, and experienced side effects, with OR $(95 \% \mathrm{CI})$ of $0.23(0.07$ $0.77), \quad 0.35$ (0.13-0.95), 0.30 (0.08-0.58), and 0.04 (0.04-0.39), respectively. The results from FGD and IDIs strengthened the findings that the experience of nausea, organoleptic properties of iron-folic acid tablet, forgetfulness, and mother's support play important roles in students' acceptability. Conclusion: This study found moderate acceptability towards the WIFS programme. The inhibiting and reinforcing factors of WIFS acceptability in this study could be considered as inputs for programme improvements in the future.
\end{abstract}

Keywords: Adolescent girls, Indonesia, programme acceptability, school-based programmes, weekly iron-folic acid supplementation

\footnotetext{
*Corresponding author: Dr. rer.nat.dr. BJ. Istiti Kandarina

JL. Farmako, Sekip Utara, Mlati, Sleman Regency, Special Region of Yogyakarta, Indonesia 55281

Telephone/Fax: +6274 547915 ext. 547923; Email: istitik@ugm.ac.id

doi: https://doi.org/10.31246/mjn-2020-0019
} 


\section{INTRODUCTION}

Iron deficiency anaemia (IDA) is the third most important cause for the lost in disability-adjusted life years (DALYs) in adolescents worldwide at 3\%, behind alcohol and unsafe sex (Gore et al., 2011). There was a significant increase in the prevalence of anaemia in the population aged $15-24$ years from $18.4 \%$ in 2013 to $32 \%$ in 2018, while data in 2013 showed that anaemia in adolescent girls aged 5-14 years was 26.4\% (Kemenkes RI, 2013; Kemenkes RI, 2018) and about $40 \%$ in Yogyakarta City (Sudargo, Juffrie $\&$ Widiarsanti, 2012). Menstrual blood loss and increasing iron requirements during rapid growth make adolescent girls more vulnerable to be anaemic compared to males (WHO, 2016). Good health and nutritional status of this population will later determine their adult health and their children's health. It is well documented that anaemic women may have more risk to deliver a low birth weight and stunted baby (Koura et al., 2012).

Based on this growing public health problem, the $65^{\text {th }}$ World Health Assembly (WHA) is committed to cut the prevalence of anaemia among adolescent girls and reproductive women in half by 2025 (WHO, 2012). The Government of Indonesia is also committed to reaching this target reduction and has been giving weekly iron-folic acid supplementation (WIFS) through a blanket approach to adolescent school girls as part of the national anaemia control programme since 2016. All adolescent girls at school should receive and consume weekly ironfolic acid (IFA) tablet supplementation throughout the year (Kemenkes RI, 2016). This approach was recommended by the World Health Organization (WHO) for areas where endemic anaemia is $>20 \%$ (WHO, 2011). The weekly iron supplementation is known to be more suitable and effective in preventing anaemia among adolescents compared to daily supplementation (AngelesAgdeppa et al., 1997). However, some factors which influenced the success of this WIFS programme at school were documented such as inadequate IFA tablet supply, lack of awareness and support from school teachers and parents, and low acceptability of the programme (Darnton-Hill \& Mkparu, 2015; Roche et al., 2018).

The acceptability of a programme is one of the implementation outcome indicators which is considered particularly important for the success of health intervention, including the WIFS programme (Proctor et al., 2011). The behaviour of adolescent school girls, especially in terms of their degree of uptake and adherence towards the weekly IFA tablet consumption, was defined as acceptability in this case (Sekhon, Cartwright \& Francis, 2018). Even though the benefits of IFA tablet supplementation are very well understood and the availability of IFA tablet is more than enough, some uncertainties still exist after the adolescent school girls have received the tablet on whether they will consume it on a weekly basis or not. Some previous studies reported several factors may influence the acceptability of the WIFS programme, such as the support from peers, teachers and parents, the experience of gastrointestinal discomfort, and the organoleptic properties of IFA tablet (Dhikale et al., 2015; Nuradhiani, Briawan \& Dwiriani, 2017; Sajna \& Jacob, 2017).

The Yogyakarta District Health Office first began implementing this WIFS programme among adolescent school girls with an IFA tablet distribution coverage reaching about $65.4 \%$ in 2016. Since this programme is newly implemented and there has been no documentation on the number of IFA 
tablets consumed, a study is needed to explore the acceptability and its influencing factors. This study will provide good insights for health policy makers to achieve the main objective of the WIFS programme.

\section{MATERIALS AND METHODS}

\section{Setting and study design}

This study was conducted from January to April 2018 in two sub-districts in Yogyakarta city with a mixed-methods sequential explanatory approach. The study was conducted in the middle of the WIFS programme implementation in schools. At first, a cross-sectional survey was done to assess the prevalence of iron deficiency anaemia, quantify selfreported consumption of IFA tablets during the previous week, and determine the factors which may influence the acceptability of WIFS among adolescent school girls. Following the survey, qualitative method was subsequently applied to explore and enrich the findings from the cross-sectional survey on adolescent school girls' acceptability and school teachers' experiences towards the WIFS programme. The cross-sectional survey involved 211 participants who were randomly selected among first and second grade registered students from three junior and three senior high schools in Yogyakarta City. All students from the $3^{\text {rd }}$ grade were not involved in the study since the national final exam preparation was held then by each school. The selected six schools were distributed in the Tegalrejo and Gondomanan sub-districts, which were purposely chosen based on the number of IFA supplementation distribution coverage. Tegalrejo and Gondomanan were considered as areas with the highest (100\%) and lowest (13\%) distribution coverage of the IFA supplementation programme for schools in 2016. The rationale of this area selection method was to identify whether higher proportion of IFA tablet distribution would have a correlation with higher compliance (number of IFA tablet consumed/number of IFA tablet distributed) and hence lesser anaemia prevalence.

\section{Subjects and data collection}

The inclusion criteria of subjects were adolescent school girls aged 12-18 years old and willing to participate in the study by completing the informed consent and assent forms. The study team excluded subjects who were menstruating at data and blood sample collection period. All consenting subjects were assessed for their nutritional and anaemia status, habitual food intake, and acceptability towards the on-going WIFS programme in their schools. Their weight and height were measured to determine body mass index (BMI)-for-age $z$-score, which was calculated by using the WHO AnthroPlus version 3.1 software. All respondents provided blood samples for assessing anaemia status based on the laboratory analysis of haemoglobin $(\mathrm{Hb})$ and serum ferritin (SF). The assessments of $\mathrm{Hb}$ and SF were done in VitMin Lab, Willstaett, Germany and examined using the Hematoanalyzer KX-21 and ELISA method (Erhardt, 2020), respectively.

Furthermore, a pre-tested semi-quantitative food frequency questionnaire (SQ-FFQ) and a single 24hour food recall were used to assess the adequacy of recommended intake, while variation in food group consumption was assessed through the Women's Dietary Diversity Score (WDDS) questionnaire (nine food groups) (Kennedy, Ballard \& Dop, 2010). The dietary diversity score was categorised into three categories of food frequencies, namely: respondents who consumed $\leq 3$ food groups, 4-5 food groups, and $\geq 6$ food groups in a day and they were defined as low, medium, and 
high dietary diversity, respectively. The estimation of nutrient composition from the SQ-FFQ was analysed using the Nutrisurvey software version 2007 with the Indonesian Food Composition Table (IFCT) database. The IFCT was taken from its existing source at http://www. nutrisurvey.de, which was regularly updated and added by the investigators for some packaged foods (i.e., milk, food supplement, biscuits, etc.). A recipe was formulated for mixed dishes that were not found in the available databases. The context of acceptability in this study was defined as how a student complied with consuming IFA tablets every week. This was described by selfreported consumption of the IFA tablets in the previous week. A structured questionnaire was used to measure IFA tablet knowledge, perceptual experience, organoleptic perceptions, and selfreported consumption of IFA tablets in the previous week with its influencing factors.

Qualitative data collection was done after the survey was completed, with four focus group discussions (FGDs) and four in-depth interviews (IDIs). The IDIs were done with a representative among the teachers who were in-charge of the healthy school programme (Unit Kesehatan Sekolah/UKS). The current implementation of WIFS programme in each school (including programme planning, distribution, and reporting), support and programme challenges were collected during IDSs. FGDs were conducted in four out of six schools involved in this study. Two FGDs were done in the selected Junior and Senior High Schools in Gondomanan, and the other two in Tegalrejo, purposively. Each FGD consisted of seven to eight students who were intentionally selected based on the students' self-reported WIFS acceptability from the previous cross-sectional survey. Within each FGD group, students who reported consuming
IFA tablets were mixed with students who did not take the tablets. The aim of this mixed group arrangement was to gather more valid information on the facilitating and inhibiting factors of WIFS acceptability among all FGD members. Moreover, the study team also collected information regarding knowledge on anaemia, how the participants received and consumed their IFA tablets, and parental support towards the WIFS programme among these FGD members.

This study was conducted according to the guidelines in the Declaration of Helsinki. All procedures involving human subjects / patients were approved by the Medical and Health Research Ethics Committee, Faculty of Medicine, Universitas Gadjah Mada (No. KE/ FK/0902/EC/2017). Written informed consent was obtained from all subjects / participants before their participation in the study.

\section{Data analysis}

Descriptive and multivariate analyses were performed by SPSS (Version 20.0). The findings of this study were displayed thematically - with quantitative results, followed and supported by important findings from qualitative results. Tables 1, 3 and Figure 1 are presented based on the sub-district areas to distinguish the findings between areas with high and low distribution coverage of the IFA supplementation tablet programme in 2016. The adequacy of energy and nutrient intakes in Table 2 was calculated based on the adjusted Indonesian recommended dietary allowance (RDA) 2013. The adjusted RDA was determined by comparing the actual body weight of respondents to the reference body weight table and then multiplied it with the RDA of energy and each nutrient.

Statistical significance was tested using the Mann-Whitney test for nonnormally distributed data, while chisquared test was used to measure the 
proportions for categorical variables. Furthermore, binary logistic regression test was used to determine the factors which affected acceptability (selfreported IFA tablet consumption) as the main outcome. The following variables were included in the logistic regression test: the residence of subject (subdistrict), parent's (mother and father) last education, organoleptic experiences (taste, smell, and colour), perception of IFA tablet (for increasing blood volume, red colour, unfavourable smell, and nausea), factors considered as barriers towards compliance (reported forgetfulness, low peer and parental support, unfavourable appearance, experiencing side effect, and unknown benefit), dietary diversity score, anaemia and iron deficiency, and nutritional status. The backward logistic regression method was used in logistic regression analysis to obtain the presented final model.

Meanwhile, the verbatim transcripts from the FGDs and IDIs were coded based

Table 1. General characteristics and anaemia status of respondents

\begin{tabular}{|c|c|c|c|c|}
\hline \multirow{2}{*}{ Variable } & \multirow{2}{*}{ All } & \multicolumn{2}{|c|}{ Sub-district } & \multirow{2}{*}{$p$-value } \\
\hline & & Gondomanan & Tegalrejo & \\
\hline Age, median \pm IQR & $15 \pm 3$ & $15 \pm 3$ & $14 \pm 3$ & 0.13 \\
\hline \multicolumn{5}{|l|}{ Iron deficiency (ID) ${ }^{\dagger}, n(\%)$} \\
\hline Yes $(<15 \mathrm{ug} / \mathrm{L})$ & $47(22.3)$ & $26(21.7)$ & $21(23.1)$ & 0.80 \\
\hline No ( $\geq 15 \mathrm{ug} / \mathrm{L})$ & $164(77.7)$ & $94(78.3)$ & 70 (76.9) & \\
\hline \multicolumn{5}{|l|}{ Haemoglobin (mg/dl), $n$ (\%) } \\
\hline Anaemia $(<12 \mathrm{mg} / \mathrm{dl})$ & $26(12.4)$ & $18(15.0)$ & $8(8.9)$ & 0.18 \\
\hline Normal ( $\geq 12$ mg/dl) & $184(87.6)$ & $102(85.0)$ & $82(91.1)$ & \\
\hline \multicolumn{5}{|l|}{ BMI-for-age $z$-score, n (\%) } \\
\hline Underweight $(<-2 \mathrm{SD})$ & $5(2.4)$ & $3(2.5)$ & $2(2.2)$ & 0.98 \\
\hline Normal (-2 SD to $1 \mathrm{SD})$ & $143(67.8)$ & $81(67.5)$ & $62(68.1)$ & \\
\hline Overweight (>1 SD to $2 \mathrm{SD}$ ) & $43(20.4)$ & $24(20.0)$ & 19 (20.9) & \\
\hline Obese (>2 SD) & $20(9.5)$ & $12(10.0)$ & $8(8.8)$ & \\
\hline \multicolumn{5}{|l|}{ Dietary diversity score, $n(\%)$} \\
\hline Low dietary diversity & $30(14.2)$ & $18(15.0)$ & $12(13.2)$ & 0.77 \\
\hline Medium dietary diversity & $110(52.1)$ & $64(53.3)$ & $46(50.5)$ & \\
\hline High Dietary Diversity & $71(33.6)$ & $38(31.7)$ & $33(36.3)$ & \\
\hline \multicolumn{5}{|l|}{ Mother's last education, $n(\%)$} \\
\hline$\leq$ Junior high school & $22(10.4)$ & $5(4.2)$ & $17(18.7)$ & $0.01^{*}$ \\
\hline Senior high school & $86(40.8)$ & $56(46.7)$ & $30(32.9)$ & \\
\hline University & $103(48.8)$ & $59(49.2)$ & $44(48.4)$ & \\
\hline \multicolumn{5}{|l|}{ Father's last education, $n(\%)$} \\
\hline$\leq$ Junior high school & $16(7.6)$ & $5(4.2)$ & $11(12.1)$ & 0.17 \\
\hline Senior high school & $96(45.5)$ & $58(48.3)$ & $38(41.8)$ & \\
\hline University & 99 (46.9) & $57(48.5)$ & $42(46.1)$ & \\
\hline \multicolumn{5}{|l|}{ Parent's income ${ }^{\ddagger}, n(\%)$} \\
\hline$\leq$ Minimum income rate & $73(34.6)$ & $40(33.3)$ & $33(36.3)$ & 0.66 \\
\hline$>$ Minimum income rate & $138(65.4)$ & $80(66.7)$ & $58(63.7)$ & \\
\hline
\end{tabular}

Iron deficiency (ID) was defined based on the serum ferritin parameter

${ }^{\ddagger}$ According to minimum income rate (UMR) in Yogyakarta City, 2017

"There was no significant difference between Tegalrejo and Gondomanan except for mother's last education, $p<0.05$ 
on the generated evidence or existing concepts and themed accordingly. Each theme was explored and interpreted by the researchers through narrative analysis along with related quotes and stories from participants. Opencode (Version 4.3) application was used to code the verbatim transcripts.

\section{RESULTS}

A total of 211 participants with complete information were included in the analysis. About $22.3 \%$ and $12.4 \%$ of the participants were categorised as iron deficient and anaemic, respectively. The median age of the participants was 15 years old and most of the participants were categorised as having normal nutritional status based on BMI-forage $z$-score. There were no significant differences in terms of the prevalence of anaemia and iron deficiency, nutritional status, dietary diversity status, and other general characteristics between adolescent school girls who resided in Gondomanan and Tegalrejo subdistricts, except in the proportion of the last attainment of mother's education
(Table 1). The proportion of mothers who graduated from senior high school and university in Gondomanan was higher than in Tegalrejo.

In general, the proportion of students who knew about and had ever received the tablets was not as much as those who consumed it during the last week. The overall number of students who knew about the IFA tablet supplementation in schools were 196 (93.0\%) and those who had ever received the tablets were 192 $(91.0 \%)$. However, of the students who received the tablets, only 131 (62.0\%) of them had consumed it within the last week. Compared to the self-reported consumption of IFA tablets among students in Tegalrejo (67.8\%), this proportion was slightly higher than in Gondomanan (61.7\%) (Figure 1). WIFS acceptability in Tegalrejo was better than Gondomanan, but not statistically different.

The District Health Office of Yogyakarta recommends that IFA tablet supplements are distributed to adolescent school girls weekly throughout the year and the students are

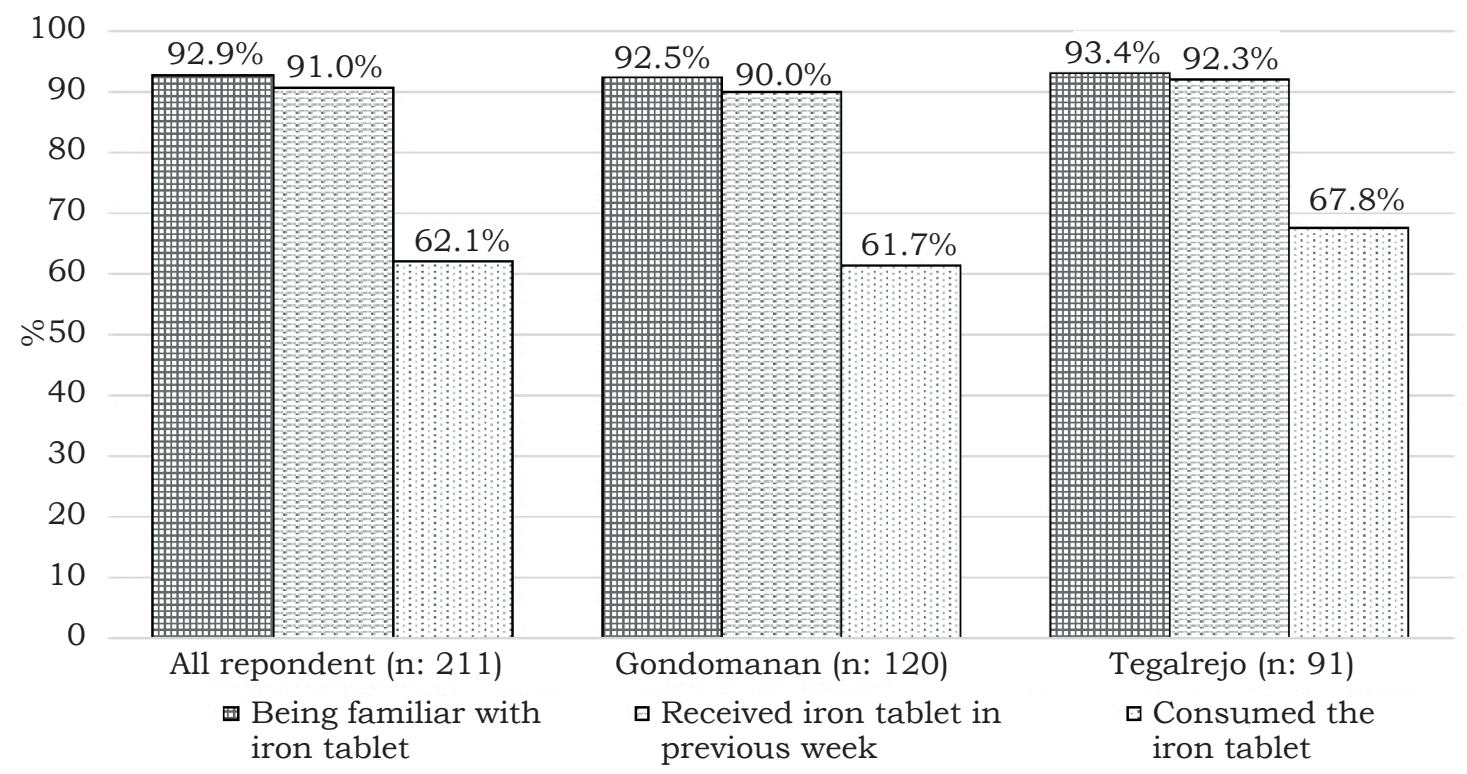

Figure 1. Cascade level of knowledge and practice in iron tablet supplementation 
asked to consume the tablets together usually every Friday (Fixed-day WIFS Programme). However, our interviews with the students showed that only one out of six schools applied this method. The remaining schools distributed the IFA tablets on an unscheduled day or even distributed them accumulatively as 12 tablets for three months and without any effort to monitor the adherence.

"Every Friday the tablet was given to us. This method was good for us which means our school's teacher was aware of us. Therefore, we do not need to keep and consume the tablet in our home" (Junior High School student, 13 years old)

Although the Yogyakarta District Health Office has encouraged the teachers and school committee to participate in the monitoring of WIFS compliance, some constraints were reported. Insufficient time, personnel and high workload of teachers in each school were the main reasons for why the "fixed-day" WIFS programme was not applied in almost all schools.

Table 2 reports the proportion of subjects who fulfilled $\geq 80 \%$ of the Indonesian recommended dietary allowance (RDA) in this study. Most of subjects met the expected RDA for vitamin A (retinol) and folic acid, but not for the remaining energy and nutrients such as carbohydrate, fat, protein, vitamin $\mathrm{C}$, Vitamin B12, and iron, which was even ranked as the least achieved. The distribution of WDDS food group consumption (nine groups) from a single 24-hour food recall supported the findings of inadequacy of these nutrients, which showed that the consumption of fruits and vegetables, as well as sources of animal protein (red meat) were the lowest proportion among other food groups at about $35.1 \%$ and $6.2 \%$, respectively.

Table 3 describes some impressions from the participants about the IFA tablets to evaluate their knowledge and perceptions towards these tablets. More than $90 \%$ of participants who resided in Gondomanan and Tegalrejo wrongly assumed that the IFA tablets may elevate "blood volume". Blood volume was defined by students as the actual amount of blood circulating in the human system. Some students also thought that IFA tablets were characterised with the colour red (24.8\%), fishy smell (14.8\%), and may make them nauseated (5.6\%). Besides that, the various reasons which explained why some students rejected to consume the IFA tablets were also captured in Table 3. The unfavourable organoleptic properties of IFA tablets $(26.2 \%)$ and the lack of peer support $(26.2 \%)$ were recognised as common factors for why some adolescent school

Table 2. The proportion of intake adequacy related to each nutrient among participants $(N=211)$, based on the Indonesian recommended dietary allowance (RDA $)^{\dagger}$

\begin{tabular}{lccc}
\hline Energy and Nutrients & Median $\pm I Q R$ & $R D A$ & $\%(\geq 80 \% R D A)$ \\
\hline Energy (kcal) & $1822 \pm 1038$ & 2312 & 51.2 \\
Carbohydrate (g) & $275.7 \pm 164.9$ & 317.0 & 60.2 \\
Fat (g) & $56.3 \pm 35.2$ & 77.0 & 44.1 \\
Protein (g) & $56.9 \pm 42.3$ & 68.0 & 54.5 \\
Vitamin A as Retinol (mcg) & $1094.4 \pm 716.1$ & 656.0 & 91.0 \\
Vitamin C (mg) & $54.8 \pm 66.6$ & 74.0 & 45.0 \\
Iron (m) & $7.5 \pm 7.8$ & 28.0 & 13.3 \\
Folic Acid (mcg) & $124.0 \pm 116.1$ & 439.0 & 91.9 \\
Vitamin B12 (mcg) & $2.1 \pm 2.5$ & 2.5 & 52.1 \\
\hline
\end{tabular}

${ }^{\dagger}$ According to adjusted Indonesian RDA 2013 
girls did not take it as a supplement, while the other $18.0 \%$ of participants in the study reported that they forgot about storing and consuming the IFA tablets. Furthermore, the experience of side effects, lack of knowledge related to the benefits of IFA tablets, and the role of parent support were also some aspects which influenced the students' motivation towards consuming the IFA tablets.

The findings from Table 3 were confirmed by the results of FGDs and IDIs with students and teachers, for example in the following quotes from the participants:

"......there was a complaint from the student after they took the tablet. They felt nausea and the odour like fishy smell...but overall they have no problem with it other than that..." (Teacher in Senior High School)

"I left the tablet in the school and put it in the desk rack...then I forgot to consume it" (Student in Junior High School, 14 years old)
The role of the parents in supporting the nutrition programme to increase compliance of the WIFS programme is also essential. Some students and teachers highlighted this as follows.

"My parent did not recommend me to consume this tablet (IFA), because my mother said that I do not need it, just leave it. Since my doctor and mother do not recommend me to consume it so then I would not take it up ....." (Student in Senior High School, 16 years old).

"Yes... from our experience in 2017, one student gave the tablet back to us. She told me that she was prohibited by her parent who was a doctor" (Teacher in Junior High School).

Table 4 shows the determinants that influence WIFS acceptability among the subjects. Variables that did not contribute significantly as determinants of WIFS acceptability were removed from the final model, which are presented in Table 4, i.e., study area, mother's and father's last education, etc. The organoleptic

Table 3. The participants' first responses regarding iron tablet supplements and reasons for not taking the tablets

\begin{tabular}{lccr}
\hline Variety of reasons & $\begin{array}{c}\text { All } \\
n(\%)\end{array}$ & $\begin{array}{c}\text { Gondomanan } \\
n(\%)\end{array}$ & $\begin{array}{c}\text { Tegalrejo } \\
n(\%)\end{array}$ \\
\hline Impression of iron tablet supplement, $N=196$ & & & \\
$\quad$ May increase "blood volume" & $180(91.8)$ & $101(91.0)$ & $79(93.0)$ \\
Red colour appearance & $48(24.8)$ & $27(24.3)$ & $21(24.7)$ \\
The fishy smell & $29(14.8)$ & $18(16.2)$ & $11(13.0)$ \\
May make nauseated & $11(5.6)$ & $4(3.6)$ & $7(8.2)$ \\
& & & \\
Reasons for the participant to not consume the & & & \\
tablet, $N=61$ & $16(26.2)$ & $6(17.6)$ & $10(37.0)$ \\
The taste and appearance are not interesting & $16(26.2)$ & $6(17.6)$ & $10(37.0)$ \\
My friend does not consume it as well & $11(18.0)$ & $10(29.4)$ & $1(3.7)$ \\
Forget to store and take it & $2(3.3)$ & $1(3.0)$ & $1(3.7)$ \\
Being nauseated & $2(3.3)$ & $2(5.9)$ & $0(0.0)$ \\
Do not know the benefits & $2(3.3)$ & $0(0.0)$ & $2(7.4)$ \\
The parents do not encourage to take it & & & \\
\hline
\end{tabular}


Table 4. Determinant factors of WIFS acceptability using multivariate logistic regression test $(N=169)^{\dagger}$

\begin{tabular}{|c|c|c|c|}
\hline Factors & $\begin{array}{c}\text { Consumed iron tablet } \\
n(\%)\end{array}$ & Adj OR (95\% CI) & p-value \\
\hline \multicolumn{4}{|l|}{ Taste experience } \\
\hline Like & $99(86.8)$ & $4.66(1.90-11.43)$ & \multirow[t]{2}{*}{$<0.01^{*}$} \\
\hline Dislike & $32(54.2)$ & Ref & \\
\hline \multicolumn{4}{|l|}{ Nutritional status } \\
\hline Underweight & $5(100.0)$ & $7.99(0.00-0.00)$ & \multirow{3}{*}{0.44} \\
\hline Normal & $112(60.2)$ & $0.24(0.02-2.12)$ & \\
\hline Obese & $16(80.0)$ & Ref & \\
\hline \multicolumn{4}{|c|}{$\begin{array}{l}\text { The smell is not good } \\
\text { (perception) }\end{array}$} \\
\hline Yes & $13(44.8)$ & $0.23(0.07-0.77)$ & \multirow{2}{*}{$0.02 *$} \\
\hline No & $118(70.7)$ & Ref & \\
\hline \multicolumn{4}{|c|}{ Reported forgetfulness } \\
\hline Yes & $50(82.0)$ & $0.35(0.13-0.95)$ & \multirow[t]{3}{*}{$0.04^{*}$} \\
\hline No & $58(49.2)$ & Ref & \\
\hline Not answered & $23(88.5)$ & - & \\
\hline \multicolumn{4}{|c|}{$\begin{array}{l}\text { My friend does not consume } \\
\text { it as well (peer support) }\end{array}$} \\
\hline Yes & $16(48.5)$ & $0.30(0.08-0.58)$ & \multirow{3}{*}{$0.03^{*}$} \\
\hline No & $92(63.0)$ & Ref & \\
\hline Not answered & $23(88.5)$ & - & \\
\hline \multicolumn{4}{|c|}{ Side effect (nausea) } \\
\hline Yes & $15(88.2)$ & $0.04(0.04-0.39)$ & \multirow{3}{*}{$<0.01^{*}$} \\
\hline No & $93(57.4)$ & Ref & \\
\hline Not answered & 23 (88.5) & - & \\
\hline
\end{tabular}

There were 27 out of 196 subjects excluded due to missing data

*Factors were significantly associated with WIFS acceptability, $p<0.05$

properties of the IFA tablets, particularly the taste, had a significant association with the willingness of respondents to consume the tablets. The respondents were more likely to take the tablet if it tasted good [OR $(95 \% \mathrm{CI}): 4.66$ (1.9011.43)]. Meanwhile, once the respondent has perceived that the odour of the tablet was not good, forgot to take and consume the tablet, had low peer support, and experienced side effects, the possibility of the respondent to take the iron tablets declined, with OR $(95 \% \mathrm{CI})$ of $0.23(0.07-$ $0.77), \quad 0.35 \quad(0.13-0.95), \quad 0.30 \quad(0.08-$ $0.58)$, and 0.04 (0.04-0.39), respectively. Respondents had more willingness to take the tablets if their close friends shared good experiences regarding IFA tablet consumption and conversely.

\section{DISCUSSION}

This study reported that about $22.3 \%$ and $12.4 \%$ of the participants were iron deficient and anaemic, respectively. There were no significant differences in the prevalences of anaemia, iron deficiency, and acceptability between the areas with high (Tegalrejo) and low (Gondomanan) IFA tablet distribution coverage. Nearly nine out of ten participants had received IFA tablet supplementation, however only $62 \%$ of them had taken the supplement based on self-reporting consumption interviews. This study found that the organoleptic properties and the perceptions of IFA tablets, reported forgetfulness, role of peer support, and experience of side 
effects after consuming IFA tablets were determinant factors that significantly influenced WIFS acceptability among adolescent school girls.

\section{The reinforcing factors}

This study showed that peer and parental support was positively correlated with high adherence. Other studies described that improving motivation by parents and good sharing experiences from close friends were facilitating factors for the success of weekly IFA supplementation programme in schools (Dhikale et al., 2015; Nuradhiani, Briawan \& Dwiriani, 2017). Therefore, engaging parents of adolescent girls concerning the programme may help to improve the compliance level of the girls with WIFS (Dubik et al., 2019).

Moreover, since the health issue includes eating behaviour of adults, which is also likely to be influenced by their peers (Salvy et al., 2012), schoolpeer group also has a significant impact for increasing the acceptability among adolescent school girls in this study. Peer support was defined as the giving of assistance and encouragement by an assumed equal individual (Dennis, 2003). The theory of the Health Belief Model revealed that the adherence of selfmanaged treatment regimens, including iron tablet supplementation, might be improved through the mechanism of functional support based on sharing of information and experience, mutual counselling, and exchange among peer support groups (Nechitilo et al., 2016).

\section{The inhibiting factors}

This study found that the organoleptic properties of IFA tablets, reported forgetfulness, and side effects were primary causes of low acceptability among adolescent school girls. The organoleptic aspects of the iron tablets, especially the flavour, was one of the determinant factors of acceptability among respondents. Some previous studies described various efforts to improve this issue, for example, the programme in India modified the colour appearance of the tablet from red to blue (Aguayo, Paintal \& Singh, 2013), another in Mexico added favourable odour into IFA tablets such as vanilla or chocolate (Morales et al., 2007), and one in Canada converted the IFA supplements from tablet to powder, even though the bioavailability of iron absorption requires further investigation and improvement (Hartman-Craven et al., 2009).

India, who implemented a large-scale national IFA supplementation among adolescent girls, also documented that the most reported reason for low compliance was forgetfulness (Aguayo, Paintal \& Singh, 2013). A similar study conducted in East Java, Indonesia described more details on the reason of low compliance among adolescent girls: being lazy, bored, losing the tablet, and lack of awareness (Susanti, Briawan \& Martianto, 2016). The programme of fixed-day WIFS at schools is one of the best actions to avert the issue of reported forgetfulness. This fixed-day activity of doing IFA tablet consumption together at school has additional benefits, both to enable the monitoring of compliance and to prevent the common reason of forgetfulness among students for not consuming the tablets. Moreover, if the teachers are able to deliver anaemia and health education prior to initiating the programme, it may raise the adherence of students through improvement of their knowledge, perceptions, and behaviour (Bandyopadhyay et al., 2017). Collaboration and commitment among the district health office, district education, and religious affair office are essentially needed to facilitate the schools or madrasah (Islamic schools) in providing the allocated time for this programme. The lessons learnt by Roche and colleagues who implemented 
a multi-sectoral project of weekly iron supplementation for adolescent girls in West Java provides an ideal example (Roche et al., 2018).

The other inhibiting factor which was faced as a challenge within this programme was the side effects experienced, especially gastrointestinal problems. Two studies revealed that the experiences of nausea, vomiting, black stool, and diarrhoea were frequently reported as causes of low acceptability towards iron supplementation programme (Dhikale et al., 2015; Sajna \& Jacob, 2017). Some efforts can be performed to avoid these reported side effects, such as eating a meal before consuming the IFA tablets, taking the IFA tablets in smaller doses by cutting the tablet into two and consuming it in the morning and afternoon/evening, and if the side effects cannot be avoided during IFA consumption day at school, the adolescent girls are suggested to consume the tablet at night (after dinner and before going to bed) (SABM, 2013).

One of the limitations of this study was the method of measuring acceptability, which only used selfreported consumption instead of using direct observation or log books for IFA tablet consumption. During the period when this study was conducted, the programme output of WIFS only measured the coverage of IFA tablet distribution, but not the actual compliance. Therefore, this study measured the acceptability of IFA tablet consumption through asking whether the participants consumed the IFA tablets in the previous week. The strength of this study was that it is the first published study in Indonesia aimed to assess the acceptability of WIFS programme among adolescent school girls using a mixed-methods design. The findings of this study can be used as an input for the improvement of WIFS programme in the future.

\section{Recommendations for WIFS Programme improvement}

Arranging a special session or specific day every week for consuming the IFA tablets together and inserting a fun breakfast session prior to the programme may solve some inhibiting factors which were found in this study. The fixed-day programme may prevent forgetfulness of taking the tablet since it will be done together within the school. Moreover, it may ease the process of programme monitoring and reporting. Meanwhile, the fun breakfast session, combined with some health and nutrition education sessions, could be conducted in advance to reduce gastrointestinal discomfort after consuming IFA tablets and increase the health awareness among students (Bandyopadhyay et al., 2017; SABM, 2013).

In addition to that, creating a supportive environment is ultimately required to assure programme sustainability through increasing demand and support for the project among stakeholders in the school system, including school headmasters, school committee, teachers, parents, and the students themselves, who are especially essential to the success of the programme. The experiences of implementing behaviour change communication (BCC) strategy by Nutrition International and communication for development (C4D) strategy by United Nations Children's Fund (UNICEF) for health and nutrition adolescent programmes provide some excellent examples for promoting healthy role models (Roche et al., 2018; UNICEF, 2007).

\section{CONCLUSION}

The technical and practical barriers of IFA supplementation programme, especially among adolescent school girls, based on the previous discussion are still 
challenging. The acceptability, which was defined as self-reported consumption of IFA tablets in this study, was moderate. The prevalence of iron deficiency and anaemia were found to be $22.3 \%$ and $12.4 \%$, respectively. Considering the prevalence of iron deficiency and anaemia in addition to the inadequacy of energy and some nutrients intake in this study, the blanket approach for IFA supplementation programme for adolescent school girls is still needed. However, the reinforcing factors which were found in this study, i.e. peer, parental and school support should be maintained and promoted, while the various inhibiting factors (barriers), i.e., reported forgetfulness, side effects, and organoleptic properties of IFA tablet should be carefully managed for future improvement of the WIFS programme.

\section{Acknowledgments}

The authors would like to extend our thanks for the generous support from the Yogyakarta District Health Office and all students and school committees involved in the study. Our gratitude is also delivered to Dr. Judhiastuty Februhartanty and the staffs of Klinik Bahasa FK-KMK UGM for their valuable input in reviewing the manuscript.

\section{Authors' contributions}

MRA, designed the protocol of the study, analysed the data, led the first article drafting; BJIK, designed the protocol of the study; NK, designed the protocol of the study, analysed the data; DY, led the data collection and compiled all verbatim transcripts; MF, led the data collection and compiled all verbatim transcripts; $\mathrm{RF}$, led the data collection and compiled all verbatim transcripts. All authors had reviewed and agreed to the content of the manuscript.

\section{Conflict of interest}

The authors report no conflicts of interest in this work. This work was supported by a grant from the Medical Faculty of Universitas Gadjah Mada. The Medical Faculty of Universitas Gadjah Mada had no role in the design, analysis or writing of this article.

\section{References}

Aguayo VM, Paintal K \& Singh G (2013). The adolescent girls' anaemia control programme: a decade of programming experience to break the inter-generational cycle of malnutrition in India. Public Health Nutr 16(9):1667-1676. doi:10.1017/S1368980012005587.

Angeles-Agdeppa, I., Schultink, W., Sastroamidjojo, S., Gross, R., \& Karyadi, D. (1997). Weekly micronutrient supplementation to build iron stores in female Indonesian adolescents. Am J Clin Nutr 66(1):177-183. https://doi. org/10.1093/ajcn/66.1.177

Bandyopadhyay L, Maiti M, Dasgupta A \& Paul $B$ (2017). Intervention for improvement of knowledge on anemia prevention: a schoolbased study in a rural area of West Bengal. Int $J$ Heal Allied Sci 6(2):69-74. doi:10.4103/ijhas. IJHAS_94_16.

Darnton-Hill I \& Mkparu UC (2015). Micronutrients in pregnancy in low- and middle-income countries. Nutrients 7(3):1744-1768. doi:10.3390/nu7031744.

Dennis CL (2003). Peer support within a health care context: a concept analysis. Artic Int $J$ Nurs Stud 40:321-332. doi:10.1016/S00207489(02)00092-5.

Dhikale P, Suguna E, Thamizharasi A \& Dongre A (2015). Evaluation of weekly iron and folic acid supplementation program for adolescents in rural Pondicherry, India. Int $\mathrm{J}$ Med Sci Public Heal 4(10):1360-1365. doi:10.5455/ ijmsph.2015.14042015280.

Dubik SD, Amegah KE, Alhassan A, Mornah LN \& Fiagbe L (2019). Compliance with weekly iron and folic acid supplementation and its associated factors among adolescent girls in Tamale Metropolis of Ghana. J Nutr Metab 2019:8242896. doi:10.1155/2019/8242896.

Erhardt, Juergen (2020). Measurement of the vitamin $A$ and iron status in blood samples. From http://www.nutrisurvey.de/blood samples/[Retrieved June 6 2020].

Gore FM, Bloem PJ, Patton GC, Ferguson J, Joseph V, Coffey C, Sawyer SM \& Mathers CD (2011). Global burden of disease in young people aged 10-24 years: a systematic analysis. Lancet 377(9783):2093-2102. doi:10.1016/ S0140-6736(11)60512-6. 
Hartman-Craven B, Christofides A, O'Connor DL \& Zlotkin S (2009). Relative bioavailability of iron and folic acid from a new powdered supplement compared to a traditional tablet in pregnant women. BMC Pregnancy Childbirth 9(1):33. doi:10.1186/1471-2393-9-33.

Kemenkes RI (2013). Riset Kesehatan Dasar Tahun 2013. Kemenkes RI, Jakarta, Indonesia. From http:/ /labdata.litbang.kemkes.go.id/images / download/laporan/RKD / 2013 / Laporan_ riskesdas_2013_final.pdf [retrieved February 10 2021].

Kemenkes RI (2016). Pedoman Pencegahan dan Penanggulangan Anemia Pada Remaja Putri dan Wanita Usia Subur (WUS). Kemenkes RI, Jakarta, Indonesia.

Kemenkes RI (2018). Hasil Utama Riset Kesehatan Dasar Tahun 2018. Kemenkes RI, Jakarta, Indonesia.

Kennedy GL, Ballard T \& Dop M (2010). Guidelines for Measuring Household and Individual Dietary Diversity. EC FAO, Rome, Italy.

Koura GK, Ouedraogo S, Le Port A, Watier L, Cottrell G, Guerra J, Choudat I, Rachas A, Bouscaillou J, Massougbodji A \& Garcia A (2012). Anaemia during pregnancy: impact on birth outcome and infant haemoglobin level during the first 18 months of life. Trop Med Int Health 17(3):283-291. doi:10.1111/j.13653156.2011.02932.x.

Morales J, Vargas F, Cassís L, Sánchez E \& Villalpando S (2007). Sensorial evaluation of nutritional supplements (PROGRESA) enriched with 3 different forms of iron in a rural Mexican community. J Food Sci 73(1): S1-S5. doi:10.1111/j.1750-3841.2007.00581.x.

Nechitilo M, Nguyen P, Webb-Girard A, GonzalezCasanovz I, Martorell R, DiGirolamo A \& Ramakrishnan U (2016). A qualitative study of factors influencing initiation and adherence to micronutrient supplementation among women of reproductive age in Vietnam. Food Nutr Bull 37(4):461-474. doi: $10.1177 / 0379572116647830$.

Nuradhiani A, Briawan D \& Dwiriani CM (2017). Dukungan guru meningkatkan kepatuhan konsumsi tablet tambah darah pada remaja putri di Kota Bogor. J Gizi dan Pangan. doi:10.25182/jgp.2017.12.3.153-160.
Proctor E, Silmere H, Raghavan R, Hovmand P, Aarons G, Bunger A, Griffey R \& Hensley M (2011). Outcomes for implementation research: conceptual distinctions, measurement challenges, and research agenda. Administration and Policy in Mental Health and Mental Health Services Research. https://doi. org/10.1007/s 10488-010-0319-7

Roche ML, Bury L, Yusadiredjai IN, Asri EK, Purwanti TS, Kusyuniati S, Bhardwaj A \& Izwardy D (2018). Adolescent girls' nutrition and prevention of anaemia: a school based multisectoral collaboration in Indonesia. $B M J$ 363:1-6. doi:10.1136/bmj.k4541.

SABM (2013). A Physician's Guide to Oral Iron Supplements. The Society for the Advancement of Blood Management. https://www.sabm. org/wp-content/uploads / 2019/01/2A2PhysiciansGuideOralIron.pdf [Retrieved January 24 2020].

Sajna MV \& Jacob SA (2010). Adherence to weekly iron and folic acid supplementation among the school students of thrissur corporation-a cross sectional study. Int $J$ Community Med Public Heal 4(5):1689-1694. doi:10.18203/23946040.ijcmph20171785.

Salvy SJ, de la Haye K, Bowker JC \& Hermans RC (2012). Influence of peers and friends on children's and adolescents' eating and activity behaviors. Physiol Behav 106(3):369-378. doi:10.1016/J.PHYSBEH.2012.03.022.

Sekhon, M., Cartwright, M., \& Francis, J. J (2018). Acceptability of health care interventions: A theoretical framework and proposed research agenda. $\mathrm{Br} J$ Health Psychol. https://doi. org/10.1111/bjhp. 12295.

Sudargo T, Juffrie M \& Widiarsanti E (2012). Faktor-Faktor Yang Berhubungan Dengan Kejadian Anemia Dan Kurang Energi Kronik Pada Remaja Putri Di Kota Yogyakarta. ETDUGM, Yogyakarta.

Susanti Y, Briawan D \& Martianto D (2016). Suplementasi besi mingguan meningkatkan hemoglobin. J Gizi Pangan 11(1):27-34.

UNICEF (2017). UNICEF 2017 Report on Communication for Development. From https:/ / www.unicef.org/reports / communicationdevelopment-c4d-2017 [Retrieved Jan 21 2021]. 
WHO (2011). Guideline: Intermittent Iron and Folic Acid Supplementation in Menstruating Women. World Health Organization, Geneva.

WHO (2012). 65th World Health Assembly. Prevention and Control of Non-Communicable Diseases. World Health Organization, Geneva. From http://apps.who.int/gb/ebwha/ pdf_files/WHA65-REC1/A65_REC1-en. pdf\#page $=65$ [Retrieved Jan 21 2021].
WHO (2016). Guideline: Daily Iron Supplementation in Adult Women and Adolescent Girls. World Health Organization, Geneva. From https:// apps.who.int/iris/handle/10665/204761 [Retrieved Jan 21 2021]. 